\title{
Screening Common Bean (Phaseolus vulgaris L.) Germplasm for Resistance against Angular Leaf Spot (Pseudocercospora griseola) Disease under Field Condition
}

\author{
Yayis Rezene $^{1} \&$ Shiferw Mekonin ${ }^{1}$ \\ ${ }^{1}$ Southern Agricultural Research Institute (SARI), P.O. Box 06 Awassa, Ethiopia \\ Correspondence: Southern Agricultural Research Institute (SARI), P.O. Box 06 Awassa, Ethiopia. E-mail: \\ rezene77@gmail.com
}

Received: December 26, 2018

Accepted: January 11, 2019 Online Published: February 12, 2019

doi:10.5539/jps.v8n1p30

URL: https://doi.org/10.5539/jps.v8n1p30

\begin{abstract}
Angular leaf spot (ALS) caused by the fungus Pseudocercospora griseola is one of the most destructive disease in Latin America and eastern Africa countries. The fungus, $P$. griseola is highly variable and a diverse sources of resistance genes is required to manage this economically important disease. The use of genetic resistance is the most practical and economic way to manage angular leaf spot of the common bean. Common bean (Phaseolus vulgarise L.) germplasm were screened for resistance against Angular leaf spot (ALS) under field conditions at Wonodogenet and Areka Research farms. Out of 300 common bean accessions evaluated only 14 (4.6\%) common bean accessions were resistant to naturally epidemics of angular leaf spot disease under field condition. Therefore, all common bean germplasm that showed resistance reaction can be involved in breeding program for the improvement of the common bean.
\end{abstract}

Keywords: screening, angular leaf spot disease, disease reactions

\section{Introduction}

Common bean (Phaseolus vagaries L.) one of the most important pulse crop in terms of nutrition, food security and economy, is cultivated in different regions of Ethiopia (Lemessa and Tessfaye, 2005). Among the most cause of poor yield in common bean production includes fungal, bacterial and viral diseases (Ferreira et al., 2003; Rezene et al., 2018). Angular leaf spot caused by Pseudocercospora griseola, may induce up to 40 to $80 \%$ yield loss when a susceptible variety is grown in a region with cool to moderate temperatures $\left(13-26{ }^{0} \mathrm{C}\right)$ and abundant moisture (Lemessa et al., 2011).

Several strategies can be used to manage angular leaf spot but the use of genetically resistant common bean cultivars is the most effective controlling measures farmers to adopt (Pastor-Corrales et al., 1998; Schwartz et al., 1999; Wagara et al., 2003). The main drawback to resistant cultivars is the possible breakdown of the resistance caused by adaptation of the pathogen to host resistance (Guzman et al., 1979; McDermott et al., 1993). A number of exotic sources of ALS resistance do exist and have been utilized in breeding programs targeting ALS and the cultivars with sources of resistant includes Mexico 54, MAR1, MAR2, AND277, G5686, G10909 and G10474 (Mahuku et al., 2003; Caixeta et al., 2005). Besides, majority of resistance sources are with a climbing growth pattern; such attributes are not readily accepted by farmers in Africa at large (Beebe et al., 1981) and specifically in Ethiopia. But landraces and introductions with bush type growth habit adapted and maintained by farmers have for a long time been known to have useful agronomic traits. Indeed, most existing resistant sources developed elsewhere, have been derived from landraces (Busogoro et al., 1999). For instance, G5686, which is a good source of ALS resistance and a member of the ALS differential set, is a landrace that originated from Ecuador (Mahuku et al., 2009). Though resistance may exist in bean collections, the high degree of genetic variability of $P$. griseola often compromises the use of ALS resistance derived from landraces (Nietsche et al., 2001). This is due to continuous emergency of new races, which break down disease resistance (Young et al., 1998). Hence, the need for continuous screening of germplasm to identify new sources of resistance that can regularly be introgressed into commercial cultivars (Young \& Kelly, 1996). This will counteract the new emerging races and reinforce resistance in existing ALS resistant sources.

Therefore, this screening study was conducted to asses and identify resistant common bean accessions to be used 
in the breeding program to develop resistant cultivar.

\section{Materials and Methods}

\subsection{Experimental Site and Design}

The experiment was carried out at the Wondogenet and Areka research stations located in southern Ethiopia, respectively at N07'03.968' E037'41.124' and 1803 m.a.s.l and $7^{\circ} 4^{\prime} 0^{\prime \prime} \mathrm{N}, 37^{\circ} 42^{\prime} 0^{\prime \prime} \mathrm{E}$ and 1774 m.a.s.l with an average precipitation $1290 \mathrm{~mm}$. These two locations are known for high infestation of the angular leaf spot disease. Both experimental sites were selected based on the basis of history of ALS disease infestation. Hence, the two screening areas are appropriate sites for screening common bean genotypes resistance against angular leaf spot disease. Common bean germplasms were evaluated with 2 rows of $3 \mathrm{~m}$ length in Augmented design with randomized incomplete design (Lin, \& Poushinsky,1983). The materials were evaluated under natural disease epidemics in three different environments. ALS disease severity was recorded at 55 and 66 days after planting using the 1-9 CIAT scale (Van Schoonhoven and Pastor-Corrales, 1987), where 1= no visible symptom and $9=$ disease covering more than $25 \%$ of foliar tissue.

\subsection{Plant Materials}

A total of 300 common bean germplasm including large world collections lines and varieties and standard checks known for the angular leaf spot resistance genes obtained from different countries of breeding program were included in this study.

\subsection{Statistical Analysis}

Mean ALS disease scoring data from each common bean germplasm were examined and used for data analysis. Data from ALS disease severity were subjected to analysis of variance using SAS version 3.2 (Lin, \& Poushinsky, 1983) using PROC GLM Augmented Micro SAS procedure.

\section{Result and Discussion}

Existence of highly significant $(<1 \%)$ variation for the disease severity among common bean germplasm tested under field conditions indicates variability for resistance among the accessions for the angular leaf spot disease under field condition (Table 1, Figure 1). The maximum disease reactions were recorded for most of germplasm. In other study over 1300 bean accessions were screened under field condition for anthracnose and angular leaf sport resistance and among the accessions few of the accessions found to be with resistance reaction (Schwartz, et al., 1982). Based on the current study 15 lines /accessions (Table 2) with resistance reactions to the angular leafspot under the field conditions were selected for further evaluation under greenhouse condition. Out of the accessions Acc\#299 a small red seeded bean showed high resistance to the ALS disease at both test locations. Hence, these accessions showing resistance are potential for developing broad and durable ALS resistance

\subsection{Implications in Common Bean Breeding}

These day's development of cultivars with improved angular leaf spot disease resistance is one of the main goal of common bean breeding programs. The development of resistance cultivar requires best adapted parental lines with known resistance genes. This is due to continuous emergency of new ALS races, which break down disease resistance (Young et al., 1998). ALS race distribution from the bean growing areas of Ethiopia and reaction of common bean genotypes has been studied and reported by Rezene et al., (2018). A wide frequency variation in the differential cultivars were also reported by the same authors. Most of the common bean differentials were compatible to the Ethiopia angular leaf spot races. Hence, the need for continuous screening of germplasm to identify new sources of resistance that can regularly be introgressed into commercial cultivars (Young \& Kelly, 1996). Therefore, the selected resistance from the current screening study will be refined and used in the common bean improvement program. 
Table 1. Mean square of common bean germplasm under different environment for angular leaf spot disease

\begin{tabular}{llllll}
\hline \multicolumn{6}{l}{ Mean Square } \\
\hline Source & DF & ALSW16 & ALSW17 & ALSA17 & ALSCOMB \\
\hline Block & 5 & $0.2222 N S$ & $0.0889 N S$ & $2.2805 N S$ & $0.1343 N S$ \\
Treatment & 299 & $3.6484^{* *}$ & $2.1019^{* *}$ & $1.775^{* *}$ & $1.1673^{* *}$ \\
Tests & 287 & $2.2176^{* *}$ & $1.71875^{* *}$ & $1.4911^{* *}$ & $0.8698^{* *}$ \\
Controls & 11 & $32.7676^{* *}$ & $11.4076^{* *}$ & $9.3169^{* *}$ & $6.2456^{* *}$ \\
Tests vs Controls & 1 & $94.0444^{* *}$ & $9.7187^{* *}$ & $0.2007^{* *}$ & $23.6903^{* *}$ \\
Error & 55 & 0.2101 & 0.0888 & 0.8806 & 0.0891 \\
\hline
\end{tabular}

*- significant at $5 \%$ (level of significance) NS=Non-Significant

p-Value $<0.05 \%$ - Significant at $5 \%(*)$, p-Value $<0.01$-Sigifican $1 \%(* *)$

\begin{tabular}{lllll}
\hline R-square & 0.99 & 0.99 & 0.92 & 0.99 \\
CV & 8.47 & 5.99 & 19.33 & 5.92 \\
ALS Mean & 5.41 & 4.07 & 4.85 & 5.04 \\
\hline
\end{tabular}

$\mathrm{DF}=$ degree freedom, ALSW16= angular leaf spot from Wondogenet during 2016, ALS W17 =angular leafspot from Wodogenet during 2017, ALSA17= angular leaf spot from Areka during 2017.

Table 2. Common bean germ plasm that showed resistance reaction under field condition at Wondogenet (ALSW16 \&ALS17) and Areka (ALSA17), Ethiopia during 2016 and 2017 cropping seasons

\begin{tabular}{|c|c|c|c|c|c|c|c|}
\hline & & ALSW16 & ALSW17 & ALSA17 & ALSCOM & & \\
\hline Accessions & Genotype & \multicolumn{4}{|c|}{ ALS Adjusted mean score (1-9) } & Growth habit & Seed colour \\
\hline Acc\#272 & KG27-13 & 1.8 & 3.1 & 3.2 & $2.1(\mathrm{R})$ & VINE & RED M \\
\hline ACC\#269 & GCI-CAL-270A & 1.8 & 2.4 & 4.2 & $2.6(\mathrm{R})$ & BUSH & RED M \\
\hline Acc\#100 & NABE4 & 3.0 & 1.6 & 2.7 . & $2.7(\mathrm{R})$ & BUSH & RED M \\
\hline Acc\#181 & AFR612 & 2.1 & 2.7 & 3.7 & $2.7(\mathrm{R})$ & BUSH & RED M \\
\hline Acc\#194 & SAB618 & 3.1 & 2.9 & 2.7 & $2.9(\mathrm{R})$ & BUSH & RED M \\
\hline ACC\#98 & CHEUPE & 2.0 & 2.2 & 4.2 & $3.0(\mathrm{R})$ & BUSH & WHITE \\
\hline Acc\#183 & AND279 & 2.1 & 1.6 & 5.2 & $3.0(\mathrm{R})$ & BUSH & RED M \\
\hline Acc\#255 & SUGER131 & 1.0 & 3.1 & 5.7 & $3.0(\mathrm{R})$ & VINE & CRANS \\
\hline Acc\#86 & MISHINDI & 2.0 & 2.9 & 3.7 & $3.1(\mathrm{R})$ & BUSH & GREY \\
\hline Acc\#142 & AW-SPS-51 & 2.0 & 2.9 & 2.4 & $2.6(\mathrm{R})$ & BUSH & S RED \\
\hline Acc\#188 & DAB246 & 3.1 & 4.9 & 1.2 & $3.1(\mathrm{R})$ & BUSH & RED M \\
\hline Acc\#268 & UYOLE & 3.8 & 3.1 & 5.2 & $3.1(\mathrm{R})$ & BUSH & RED M \\
\hline Acc\#185 & ROZO KOBO & 3.1 & 4.9 & 1.7 & $3.2(\mathrm{R})$ & BUSH & RED M \\
\hline Acc\#95 & TYGER BERG & 5.0 & 3.7 & 1.7 & $3.4(\mathrm{R})$ & VINE & CRANS \\
\hline Acc\#299 & SPS50-HB & 1.2 & 2.4 & 1.7 & $1.8(\mathrm{R})$ & BUSH & RED S \\
\hline \multicolumn{8}{|c|}{ Standard Checks } \\
\hline MEX-54 & & 3.0 & 2.9 & 1.7 & $3.4(\mathrm{R})$ & VINE & Pink \\
\hline AND277 & & 1.3 & 2.3 & 3.2 & $2.1(\mathrm{R})$ & BUSH & REDM \\
\hline $\mathrm{CV}$ & & 7.2 & 9.2 & 19.3 & 5.9 & & \\
\hline LSD & & 5.41 & 4.07 & 4.85 & 5.04 & & \\
\hline
\end{tabular}

ALS disease evaluations using a 1 to 9 rating scale, where $1=$ no visible symptoms of the disease and $9=$ very severe symptoms (Schoonhoven \& Pastor-Corrales, 1987). ALS reaction type: 1-3 = resistant $(\mathrm{R}) ; 4-6=$ intermediate (I); 7-9 = susceptible (S), here we have selected those genotypes showing resistance(R) reactions to the angular leaf spot under field condition. 


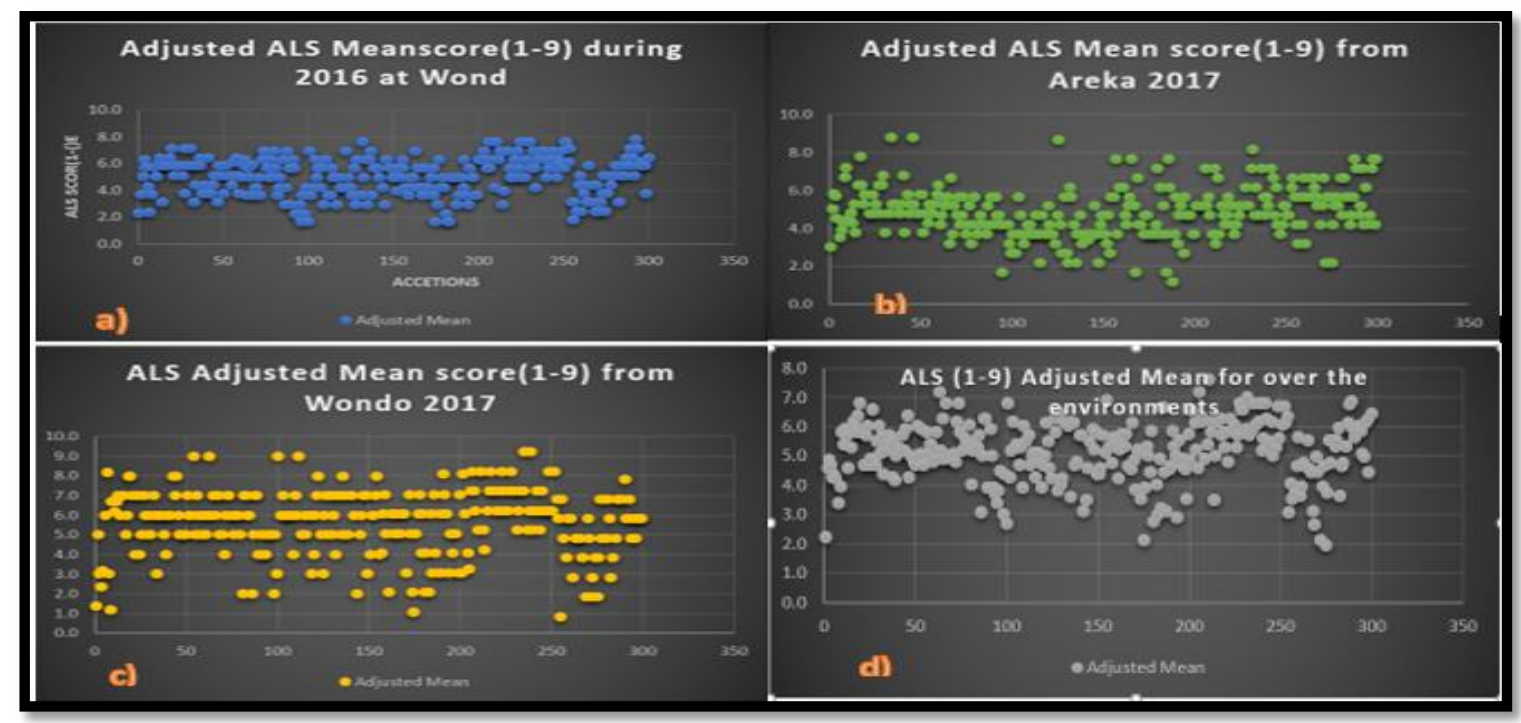

Figure 1. Adjusted mean disease severity score (1-9) for 300 common bean germplasm a) at Wondogenet 2016, b) Areka 2017, c)Wondogenet 2017 and d)the reaction across all environment. Accession their adjusted mean scores under 4 were all with resistance reaction to the naturally epidemic angular leaf spot disease

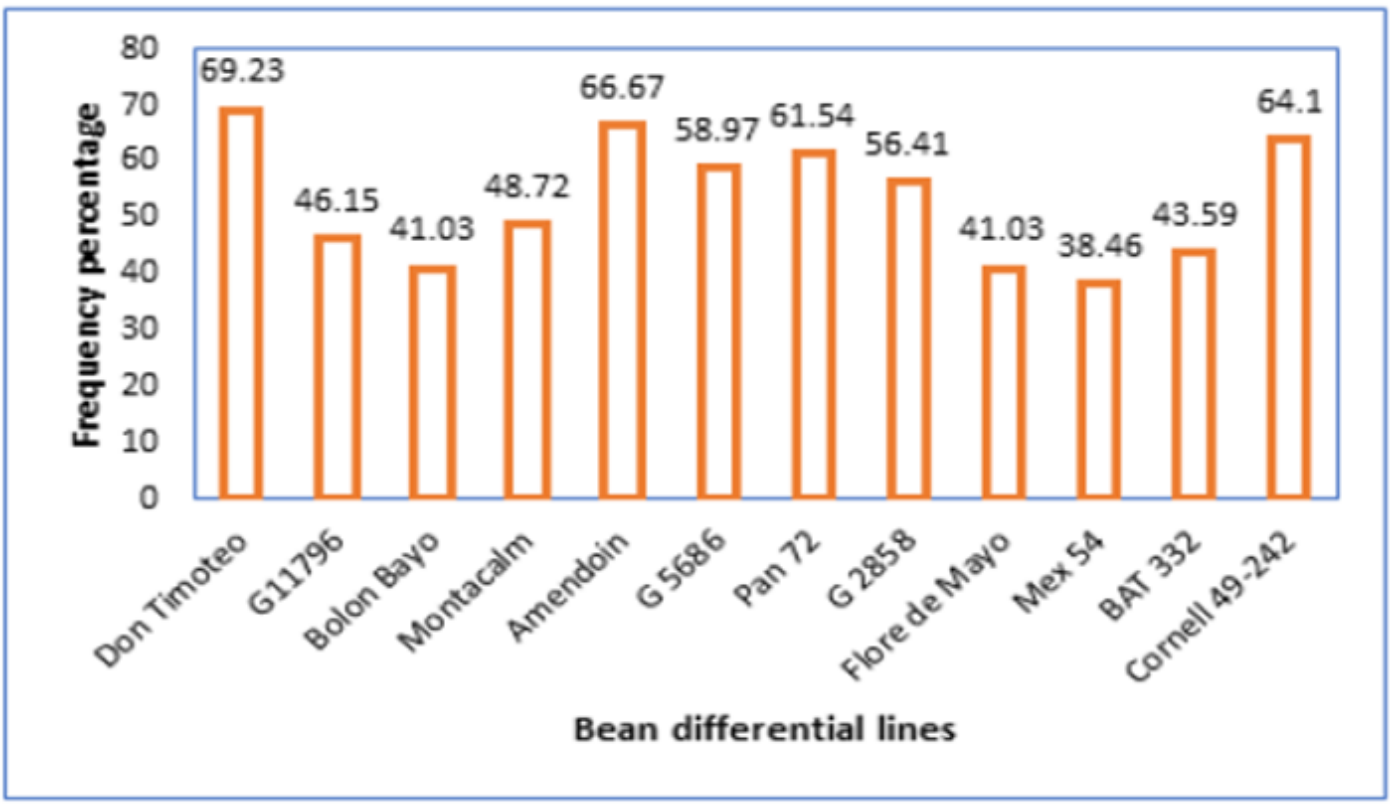

Figure 2. Frequency (\%) of compatible reaction between sets of differential common bean genotypes and evaluated isolates

Source: Rezene et al., 2018

\section{Acknowledgement}

The authors would also thank the south Agricultural Research Institute (SARI) and the ABC partner countries.

\section{References}

Beebe, S. E., Bliss, F. A., \& Schwartz, H. F. (1981). Root rot resistance in common bean germplasm of Latin American origin. Plant Dis, 65, 485-489. https://doi.org/10.1094/PD-65-485

Beebe, S. E., Rao, I. M., Cajiao, C., \& Grajales, M. (2008). Selection for drought resistance in common bean 
also improves yield in phosphorus limited and favorable environments. Crop Science, 48(2), 582-592. https://doi.org/10.2135/cropsci2007.07.0404

Busogoro, J. P., Jijakli, M. H., \& Lepoivre, P. (1999). Virulence variation and RAPD polymorphism in African isolates of Phaeoisariospis griseola (Sacc.) Ferr., the causal agent of angular leaf spot of common bean. European Journal of Plant Pathology, 105(6), 559-569. https://doi.org/10.1023/A:1008707101645

Caixeta, E. T., Borém, A., Alzate-Marin, A. L., de Azevedo Fagundes, S., e Silva, M. G. D. M., de Barros, E. G., \& Moreira, M. A. (2005). Allelic relationships for genes that confer resistance to angular leaf spot in common bean. Euphytica, 145(3), 237-245. https://doi.org/10.1007/s10681-005-1258-3

Holbrook, C. C., Timper, P., \& Xue, H. Q. (2000). Evaluation of the core collection approach for identifying resistance to Meloidogyne arenaria in peanut. Crop Science, 40(4), 1172-1175. https://doi.org/10.2135/cropsci2000.4041172x

Lemessa, F., \& Tesfaye, A. (2005). Evaluation of bean (Phaseolus vulgaris) genotypes for multiple resistance to angular and floury leaf spot diseases. Tropical science, 45(2), 63-66. https://doi.org/10.1002/ts.50

Lemessa, F., Sori, W., \& Wakjira, M. (2011). Association between angular leaf spot (Phaeoisariopsis griseola (Sacc.) Ferraris) and common bean (Phaseolus vulgaris L.) yield loss at Jimma, Southwestern Ethiopia. Plan. Pathol. J., 110(2), 57-65. https://doi.org/10.3923/ppj.2011.57.65

Lin, C. S., \& Poushinsky, G. (1983). A modified augmented design for an early stage of plant selection involving a large number of test lines without replication. Biometrics, 39(3), 553-561. https://doi.org/10.2307/2531083

Mahuku, G. S., Jara, C. E., Cajiao, C., \& Beebe, S. (2002). Sources of resistance to Colletotrichum lindemuthianum in the secondary gene pool of Phaseolus vulgaris and in crosses of primary and secondary gene pools. Plant Disease, 86(12), 1383-1387. https://doi.org/10.1094/PDIS.2002.86.12.1383

Mahuku, G. S., Jara, C., Cajiao, C., \& Beebe, S. (2003). Sources of resistance to angular leaf spot (Phaeoisariopsis griseola) in common bean core collection, wild Phaseolus vulgaris and secondary gene pool. Euphytica, 130(3), 303-313. https://doi.org/10.1023/A:1023095531683

McDermott, J. M., \& McDonald, B. A. (1993). Gene flow in plant pathosystems. Annual review of phytopathology, 31(1), 353-373. https://doi.org/10.1146/annurev.py.31.090193.002033

Nietsche, S., Borém, A., De Carvalhos, G. A., de Paula Júnor, T. J., Ferreira, C. F., De Barros, E. G., \& Moreira, M. A. (2001). Genetic diversity of Phaeoisariopsis griseola in the State of Minas Gerais, Brazil. Euphytica, 117(1), 77-84. https://doi.org/10.1023/A:1004096421990

Pastor-Corrales, M. A., Jara, C., \& Singh, S. P. (1998). Pathogenic variation in, sources of, and breeding for resistance to Phaeoisariopsis griseola causing angular leaf spot in common bean. Euphytica, 103(2), 161-171. https://doi.org/10.1023/A:1018350826591

Rezene, Y., Tesfaye, K., Clare, M., \& Gepts, P. (2018). Pathotypes Characterization and Virulence Diversity of Pseudocercospora griseola the Causal Agent of Angular Leaf Spot Disease Collected from Major Common Bean (Phaseolus vulgaris L.) Growing Areas of Ethiopia.J Plant Pathol Microbiol,9(445), 2. https://doi.org/10.4172/2157-7471.1000445

Schwartz, H. F., Corrales, M. P., \& Singh, S. P. (1982). New sources of resistance to anthracnose and angular leaf spot of beans (Phaseolus vulgaris L.). Euphytica, 31(3), 741-754. https://doi.org/10.1007/BF00039213

Wagara, N., Mwang'ombe, A. W., Kimenju, J. W., Buruchara, R. A., \& Kimani, P. M. (2003). Pathogenic variability in Phaeoisariopsis griseola and response of bean germplasm to different races of the pathogen. African Crop Science Journal Society, 6, 352-357.

Young, R. A., \& Kelly, J. D. (1996). Characterization of the genetic resistance to Colletotrichum lindemuthianum in common bean differential cultivars. Plant Disease, 80(6), 650-654. https://doi.org/10.1094/PD-80-0650

\section{Copyrights}

Copyright for this article is retained by the author(s), with first publication rights granted to the journal.

This is an open-access article distributed under the terms and conditions of the Creative Commons Attribution license (http://creativecommons.org/licenses/by/4.0/). 